\title{
"Learning is our Achilles heel". Conditions for long-term environmental policy integration in Swedish regional development programming
}

Sofie Storbjörk and Karolina Isaksson

\author{
Linköping University Post Print
}

\section{Tweet}

N.B.: When citing this work, cite the original article.

This is an electronic version of an article published in:

Sofie Storbjörk and Karolina Isaksson, "Learning is our Achilles heel". Conditions for longterm environmental policy integration in Swedish regional development programming, 2014, Journal of Environmental Planning and Management, (57), 7, 1023-1042.

http://dx.doi.org/10.1080/09640568.2013.779232

Copyright: Taylor \& Francis (Routledge): STM, Behavioural Science and Public Health Titles http://www.routledge.com/

Postprint available at: Linköping University Electronic Press http://urn.kb.se/resolve?urn=urn:nbn:se:liu:diva-93274 


\title{
"Learning is our Achilles heel" Conditions for long-term environmental policy integration in Swedish regional development programming
}

Sofie Storbjörk, Department of Water and Environmental Studies (DWES) and Centre for Climate Science and Policy Research (CSPR), Linköping University, 58183 Linköping, Sweden. Phone: +46 13 282952. E-mail: sofie.storbjork@liu.se

Karolina Isaksson, Mobility, Actors and Planning Processes (MAP), Swedish National Road and Transport Research Institute (VTI), 58195 Linköping, Sweden. Phone: +46 855577025. Email: karolina.isaksson@vti.se

Corresponding author: Sofie Storbjörk. Email: sofie.storbjork@liu.se Phone: +46 13282952.

Forthcoming in Journal of Environmental Planning and Management.

\begin{abstract}
The aim of this paper is to explore how the capacity to integrate environmental sustainability in Swedish regional development programming has evolved over time, with particular focus on what facilitates and restricts change in different stages of implementation. The study builds on focus-group and individual interviews in four Swedish regions carried out in 2005 and 2011. The results suggest temporary and partial rather than enduring and substantial environmental policy integration (EPI). In 2005 the main challenges were to allocate support, focus and priority beyond the national policy rhetoric of regional sustainable development, to identify regional applications beyond singular "pockets of good practice" and to spread ownership and engagement for EPI from specific ambassadors to organizational mainstreaming. In 2011 we find evidence of a more mainstreamed approach of regional sustainable development but with new challenges of policy diffusion and sectorisation as well as a strong sense of projectification. There is a need to develop arenas and processes for intersectoral exchange, interaction and learning to achieve a more systematic change - which is, in essence, what policy integration is all about.
\end{abstract}

Key words: environmental policy integration, regional development, implementation barriers, policy learning, organizational mainstreaming 


\section{Introduction and aim}

The integration of an environmental dimension into traditional sectoral policy domains has become a key issue in the political quest for sustainable development in many countries (Lenschow 2002, Lafferty and Hovden 2003, Nilsson and Persson 2003). Environmental Policy Integration (EPI) has been framed as processes of policy learning "in which perspectives evolve and reframe sectoral objectives, strategies and decision-making processes towards sustainable development" (Nilsson 2005, Gerger Swartling et al 2007). At the same time several studies have pointed at problems with achieving such policy integration in different sector contexts (Asplund and Skantze 2005, Arts and Leroy 2006, Krueger and Gibbs 2007, Nilsson and Eckerberg 2007, Mickwitz and Kivimaa 2007). One such example regards regional development.

In the context of regional development in Europe there have - much in line with the framing of EPI - been calls for regional sustainable development as a policy goal, where environmental, economic and social sustainability emerges as horizontal perspectives to be integrated in practical regional development programming, planning and concrete development projects (Lafferty and Narodoslawsky 2003). In the field of regional development public-private partnerships has been launched as a way to strengthen policy efficiency and coherence, accountability, inclusiveness, innovation and learning in implementation (Williams 2006, Frame and Taylor 2005). In practice however, key inertias for change have been identified, related to e.g. traditional antagonisms and contradictions between environmental, economic and social aspects of sustainable development. Further difficulties have been found in identifying regional applications and concrete outcomes of the national sustainable development rhetoric of win-win solutions between environmental and economic sustainability. Also, overcoming traditionally cemented sectorisation, finding ways to interact across sectors and spreading responsibility for sustainable development in the regional organisations and between public and private organisations have proved problematic. Similar patterns of inertias are found in Sweden (Valve and Grönqvist 2003, Håkansson et al 2007, Mobjörk 2007, Dovlén and Hilding-Rydevik 2008, Storbjörk 2008, Storbjörk et al 2009, Polk 2010, Asplund et al. 2011, Hilding-Rydevik et al 2011) and internationally (Gibbs et al 2002, Flynn et al 2003, Zamora 2003, Molitor 2003, Berger 2003).

At the same time we must consider, as Owens reflects upon, that maybe "we are looking for fundamental changes too soon" (Owens 2007:xvii). This mirrors the statement by Sabatier that implementation studies typically encompass a fairly short time-span of 4-6 years, leading to "premature judgements" about implementation failures and missing key features of policylearning processes over time (Sabatier 1986). Owens brings forth other possible "less comfortable" answers to the slow progress in suggesting that EPI necessitates a confrontation between societal goals where tough choices must be made. Still, however, the question of timing in analysis deserves to be raised (Sanderson 2000, Nilsson 2005, Kautto and Similä 2005). Although we know quite a bit about what the inertias have been for implementing EPI at the regional development arena in the early years we know less of how these conditions 
have evolved over time. We therefore take as our starting point in this paper a more longitudinal comparison of conditions for change in EPI.

The aim of this paper is to explore how the capacity to integrate environmental sustainability, has evolved over time in Swedish regional development programming and what facilitates or restrict change in different stages of implementation. The empirical base is a combination of focus-group and individual interviews with key actors in regional development and growth programming in four Swedish regions, conducted in 2005 and 2011, but referring back to activities occurring since the national policy changes in 1998.

The paper is divided in six sections. After this introduction follows the second section, introducing theoretical perspectives from the literature on EPI, implementation and policy interventions. The third section briefly gives the policy context of sustainable development at the regional development policy arena. The fourth section presents our methodological approach. In the fifth section the longitudinal analysis is organised around four thematic issues, namely the status and role of sustainable development, the relationship and coordination between key regional development actors, how a role is secured for environmental sustainability and the current projectification in regional evelopment programming. In the concluding sixth section we discuss conditions for facilitating long-term change in the perspectives and interactions of actors and organisations by relating empirical findings to theoretical assumptions.

\section{Theoretical assumptions}

Environmental policy and politics has been described as a multi-sector and multi-level field with multiple actors involved in a multitude of projects and processes which - taken at large calls for intense needs of policy coordination and policy integration (Leroy and Arts 2006). A key point of departure in this paper is the current research on environmental policy integration, EPI. EPI means incorporating or mainstreaming specific environmental policy objectives into other policy areas rather than working with environmental objectives as a separate, distinct and specialised field of its own (Lenschow 2002, Lafferty and Hovden 2003, Nilsson and Persson 2003, Nilsson and Eckerberg 2007). By making environmental sustainability a direct part of decision-making practices in other sectors, the hope is to overcome goal conflicts, policy contradictions and building synergies between ambitions and priorities as well as increasing policy making efficiency and rationality (Lafferty and Hovden 2003, Nilsson and Eckerberg 2007, Runhaar et al 2009).

We take a policy process perspective on EPI, targeting "how policy is made and organised and how opportunities and requirements for environmental consideration can be built into the process" through various tools, procedures and strategies (Persson, 2007:30, Nilsson 2005). EPI is thus seen as a wider process of policy learning amongst actors with potentially diverging belief systems, including the reframing of perspectives, objectives, problem definitions, strategies, organisational settings and decision-making processes (Nilsson 2005, Gerger Swartling et al 2007). While policy integration has the potential to overcome a lack of 
policy coordination it can however, if EPI is made at the expense of establishing a strong environmental administration, weaken rather than strengthening overall attention to environmental sustainability. Further, unless sector and environmental concerns have similar weight, the practical efforts of EPI might as well result in policy dilution, diffusion and/or evaporation where, to quote Williams, "the cutting edge and profile of cross-cutting perspectives become lost in the maelstrom of organizational machinery" (Williams 2006: 262, Liberatore 1997, Mickwitz and Kivimaa 2007).

In practice, EPI can be viewed as either resulting in slight adjustments of existing sectoral policy domains or as calling for more substantial and reformist changes and alterations of thought. A more limited form of integration is the "coordination" of policies to avoid contradictions. "Harmonization" means bringing environmental objectives on equal terms with sectoral objectives in order to promote synergies. Finally, "prioritization" means seeing environmental sustainability as an overarching principle that allows environmental objectives to be integrated into all stages of policy making as a guiding principle where historic contradictions are minimised by environmental concerns having principled priority over sectoral policies (Lafferty and Hovden 2003, Runhaar et al 2009, Jordan and Lenschow 2010). It thus appears reasonable to distinguish between different types and degrees of policy integration as a way to evaluate occurring changes. In the literature on policy arrangements, Wiering and Crabbé have distinguished between first order change as "incremental changes within routine decision-making", second order change as "development of new policy concerns and goals" and third order change as "paradigmatic shift in core values and perceptions" (Wiering and Crabbé 2006: 95f. Arts and Leroy 2006). The latter would resonate quite well with the theoretical concept of double-loop learning as "modifying values, policies and norms" where fundamental changes in behaviour is expected and existing worldviews, core values and norms challenged (Argyris and Schön, 1996, 20ff).

It is also suggested in the literature that different strategies and instruments for EPI can be used to achieve change. Four main approaches have been pinpointed: "normative approaches", e.g. political commitment and priorities of particular goals, "organisational approaches", e.g. changed departmental responsibilities and mandates, "procedural approaches", e.g. introducing new policy instruments, and finally "reframing approaches", e.g. reframing problem perceptions and fundamental ideas (Persson 2007). In assessing policy changes made we also need to distinguish between "temporary stabilisations" (Leroy and Arts 2006, Liefferink 2006) and more "enduring reorientations" (Nilsson 2005) in EPI-practice.

Further, previous studies have concluded that EPI can occur at different strategic and operational stages in policy-making, often being stronger at an agenda setting stage in comparison with later decision-making stages where conflicts of interest may arise. Persson has distinguished three stages, namely "integration of objectives in policy formulation; translation into policy measures; and implementation by government agencies and other actors" (Persson 2007, 28f.). In this paper, we primarily chose to target the third stage as this is where more severe challenges and gaps between intentions and actually occurring policy integration are expected (Asplund and Skantze 2005, Nilsson 2005, Arts and Leroy 2006, 
Krueger and Gibbs 2007, Nilsson and Eckerberg 2007, Mickwitz and Kivimaa 2007, Haveri 2008, Weale 2009).

In order to analytically tackle what may limit or trigger policy integration over time and what mechanisms of inertia are found in the implementation stage we turn to the sometimes discredited (Barrett 2004, Saetren 2005) literature on implementation and policy interventions. During the last decades this research field has evolved from an understanding of policy formulation and implementation as separate fields in a linear and rational policy process to a more complex and dynamic understanding of policy formation and implementation as being closely intertwined aspects of a policy process characterized by a continuous adjustment to the shifts in relationships, understandings and conditions that occur (Pressman and Wildawsky 1984, Jenkins-Smith and Sabatier 1994). In this paper implementation is understood as negotiated order where micro political processes, powerinterest structures and interactions between the involved actors and organisations lead to a dynamic mediation, negotiation and modification of policy as intentions are translated into action (Barrett 2004).

From previous research we conclude that implementation depends on a number of key conditions serving as explanatory factors and determinants for change, here tentatively summarized in the following categories:

1. The general policy context and historic background of the policy intervention, including the degree of political support and the relation to other interventions (Vedung 2005).

2. The clarity and complexity in policy design, where lack of clear objectives, unclear priorities and too many options for actions can leave room for differential interpretations (Barrett 2004, Vedung 2005). This also includes how the problem in question is discursively framed and represented, what the underlying presuppositions and assumptions are and what is left unanswered and unproblematised (Bacchi 2009).

3. The comprehension, administrative capability and willingness of key actors/agencies responding to the intervention. This includes aspects like the political and internal support and understanding, financial resources, personnel and equipment, bureaucratic agendas and attitudes and core beliefs expressed by involved key actors/agencies (Lipsky 1980, Lundqvist 1987, Jenkins-Smith and Sabatier 1994, Barrett 2004, Vedung 2005, Wiering and Crabbé 2006).

4. The question of when changes occur, i.e. whether the intervention comes in a formative moment or where an actor/agency is concerned with maintaining positions (Vedung 2005)

5. The multiplicity of actors/agencies involved in implementation, leading to e.g. problems of communication and coordination, conflicts of values, interests and core beliefs, differing perspectives and priorities (Jenkins-Smith and Sabatier 1994, Barrett 2004, Wiering and Crabbé 2006).

With the aim to explore how the long-term capacity to deal with EPI in the Swedish regional development context evolves over time and what the conditions are for facilitating change in different stages of implementation, our main empirical emphasis is put on conditions for 
change relating to points 3-5 above. The role of the general policy context, discursive framings and definitional dilemmas involved in policy integration will play a smaller role as the issues have been dealt with, using other data, in previous papers (e.g. Hilding-Rydevik et al 2011, Storbjörk et al 2009). More precisely our analysis will be oriented around the following analytical questions, stemming from our theoretical assumptions: What is the role and status of EPI in the regional organisations, according to key practitioners? How is the work to integrate sustainable development in regional development programming organised: what main changes or development paths can be traced? What mechanisms for EPI are built into the process of programming? What kind of change is witnessed: incremental changes or more paradigmatic reorientations? What determinants of policy integration - triggers and limitations - are found? Before empirically turning to these questions we will present a brief policy context of sustainable development at the regional development policy arena, as well as our methodological approach.

\section{Policy context: sustainable development at the regional development policy arena}

Sustainable development was introduced as a formal policy objective for Swedish regional development policy in 1998 (Swedish Government 1998). Since then, various national strategies have been developed, carrying strong messages about "sustainable growth" both as an aim and a means for achieving regional sustainable development, building on a consensual idea of the possibility to overcome polarities and harmonise economic, social and environmental dimensions of sustainable development (Hilding-Rydevik et al 2011). Further it has been stated that the sustainability perspective shall permeate all regional growth and development initiatives (Swedish Government 2010).

The 21 administrative regions are responsible for carrying out the regional development work in Sweden. It has been clearly stated that the regions themselves must be able to make priorities needed to change unsustainable trends (MIEC 2007:9). The work can be organised as part of the normal business of the county administrative boards (CAB, länsstyrelser), which is the traditional body responsible for regional governance in Sweden. It can also, if applicable, be made the responsibility of regional local self-government bodies (RLSB, regionala självstyrelseorgan) and municipal coordination bodies (MCB, kommunala samverkansorgan) that have been initiated in 16 of the Swedish regions during the past decade, propelled by ambitions to create regional governance arenas more directly linked to local and regional contexts. Despite the current region-orientated approach of EU policymaking, the regional governance level in Sweden has, by tradition, been weaker compared with the local governance level (Hilding-Rydevik et al 2011).

Swedish regional development policy has during the last decade been implemented through Regional Development Programmes (RDPs) and Regional Growth Programmes (RGPs). The RGPs are agreements between each regional body and the national government bodies, business actors and other regional actors. The RDPs are broad umbrella strategies that bind 
together regional economic strategies, infrastructure planning and municipal land-use planning. The overall aim of both RDPs and RGPs is to contribute to sustainable growth (Swedish Government 2007). In practice, the RDPs and RGPs are complemented with a multitude of more small-scale or specialised programs and funds aiming to support local and regional initiatives and processes for sustainable growth or other prioritised goals. Evaluations during the last few years have identified problems with the RDPs and RGPs, pinpointing the need for better integration and coordination of policy fields and with a clearer emphasis on sustainable development in strategies and programmes for regional growth and development (Swedish Government 2010).

\section{Methodological considerations}

Empirically we draw on two empirical studies in four Swedish regions, in the paper renamed as North, Mid, West and South. The choice to use assumed names is motivated by a willingness to avoid identification of key actors as somewhat sensitive reflections are at times allowed in the analyses. Further the case-studies are done to highlight general lessons rather than directing focus to the positive or negative elements at specific regional levels. Following Putnam's argument that regional management is so dependent on context that there is limited transferability of lessons (Putnam 1993) hopefully the use of four case-study regions gives us a better chance of providing knowledge of regional practices towards environmental policy integration. The regions were selected after an initial scanning and mapping of regional characteristics in Sweden at large where they appeared to have taken on sustainable development to a comparatively high degree. Some key regional characteristics are summarized in Table 1.

Table 1: Regional characteristics.

\begin{tabular}{|c|c|c|c|}
\hline Name: & $\begin{array}{l}\text { Regional } \\
\text { organisation: }\end{array}$ & Key features: & Environmental profile: \\
\hline Mid & RLSB & $\begin{array}{l}\text { - A large and sparsely populated } \\
\text { region in the mid part of Sweden. } \\
\text { - Industry structure traditionally } \\
\text { dominated by heavy industry, with } \\
\text { a slight shift to service and tourism. } \\
\text { - The region is struggling to uphold } \\
\text { employment and population. }\end{array}$ & $\begin{array}{l}\text { National pilot-region for } \\
\text { environmental sustainability. } \\
\text { Environmental sustainability } \\
\text { as challenge/goal for regional } \\
\text { strategies }\end{array}$ \\
\hline North & $\mathrm{CAB}$ & $\begin{array}{l}\text { - A large and sparsely populated } \\
\text { region in the northern part of } \\
\text { Sweden. } \\
\text { - Industry structure traditionally } \\
\text { dominated by basic industries e.g. } \\
\text { forestry. Manufacturing and public } \\
\text { service are also significant. } \\
\text { - The region is struggling with high } \\
\text { and increasing unemployment and } \\
\text { population decrease. }\end{array}$ & $\begin{array}{l}\text { The first "environmental } \\
\text { county" in Sweden. Long- } \\
\text { term sustainable growth and } \\
\text { sustainable development as } \\
\text { basic principles for regional } \\
\text { growth strategies }\end{array}$ \\
\hline
\end{tabular}




\begin{tabular}{|c|c|c|c|}
\hline South & MCB & $\begin{array}{l}\text { - A large region in the southern part } \\
\text { of Sweden. } \\
\text { - Industry structure traditionally } \\
\text { dominated by agriculture, fisheries } \\
\text { and industry. Service and tourism } \\
\text { are increasing. } \\
\text { - The region has experienced } \\
\text { increasing population numbers and } \\
\text { economic growth during the last } \\
\text { decade. Average unemployment } \\
\text { rates. }\end{array}$ & $\begin{array}{l}\text { Sustainability, environment } \\
\text { and climate as } \\
\text { challenges/goals for regional } \\
\text { development programmes }\end{array}$ \\
\hline West & MCB & $\begin{array}{l}\text { - A small region in the south-western } \\
\text { part of Sweden. } \\
\text { - Industry structure traditionally } \\
\text { dominated by agriculture, fisheries } \\
\text { and industry. Service and tourism } \\
\text { are increasing. } \\
\text { - The region has experienced } \\
\text { increasing population numbers and } \\
\text { economic growth during the last } \\
\text { decade. Unemployment less than } \\
\text { average }\end{array}$ & $\begin{array}{l}\text { Environmental sustainability } \\
\text { as prioritised political goal. } \\
\text { Proactive efforts lead to } \\
\text { realisation, according to } \\
\text { regional growth strategies }\end{array}$ \\
\hline
\end{tabular}

The initial case-study in the four regions took place in 2005. Two focus-groups of 4-8 participants were conducted in each of the regions in 2005. All in all 37 actors participated. Focus-group participants were broadly selected to capture experiences both of actors working with the preparation and implementation of the regional growth programmes and actors having a role in integrating horizontal themes. A selection of questions - openly formulated to learn of how sustainable development is approached in regional development programming, to explore roles and responsibilities, views, perspectives and experiences of what influences policy integration etc. - was presented during the 2-3 hour focus-group sessions to stimulate discussions on current and previous work on regional sustainable development, referring back to activities from 1998 and onwards. To compensate for important last-minute cancellations, two individual interviews were conducted. Discussions were recorded, transcribed and analysed both region-wise and at a cross-regional level. Programming documents and background material provided by the regions were also analysed. In the end of 2005, feedback-seminars of 3 hours were arranged in each region during which preliminary results were presented and discussed with regional actors, to provide a dialogical or "member checking" validation of the analysis (Silverman 1993).

Further, a recent follow-up study was done in 2011 in the same four regions. The study consisted of individual interviews with one key actor from the $\mathrm{CAB}$ and one key actor from the RLSB or the MCB (depending on the regional organisation) in each region, today working 
with regional development programming and horizontal policy integration. In the region with a traditional $\mathrm{CAB}$ the second interviewee was motivated by having been part of a previous sustainable development team with the task to facilitate policy integration. The eight interviews were done by telephone and lasted between $1-1 \frac{1}{2}$ hours each. The questions were formulated openly, stretching from how sustainable development is approached in regional development programming today, their views, perspectives and experiences of conditions influencing policy integration and the current situation compared with 2005. All interviews were recorded and transcribed.

The methodological approach of both studies takes the perspectives of key actors - their lessons and practical experiences of EPI in regional development - as its starting point. The research approach in 2005 was explorative and inductive, meaning that we did not attempt to test a particular analytical framework decided upon beforehand. Interviewees were thus not asked to comment on predefined forms of EPI but instead we aimed at openly formulated interview questions targeting their perspectives, experiences and ways of approaching policy integration. We relate our empirical findings to the EPI-literature afterwards by extracting our analysis of conditions for EPI from their stories and statements. In the follow-up study, questions were in a first step openly formulated but in a second step we also used our theoretically influenced results from the analysis made in 2005 to get their reflections on changes over time regarding specific conclusions. The qualitative analysis of data is stepwise, allowing concentration and categorization of meaning under reoccurring themes relating to indications of EPI over time. In presenting the thematic analyses, statements and reflections from involved key actors are put in focus. Here we have chosen to represent a combination of individual viewpoints and more general patterns. Although allowing singular representations - where the analysis reflects individual views, perspectives and experiences - we have generally sought to increase credibility of interpretations through data source triangulation, i.e. comparing statements from different interviews. Text analysis has also been made of a selection of regional documents, suggested by the interviewees to support their descriptions, particularly regarding facts e.g. dates, ongoing projects, exact formulations of goals etc. which allows some sense of methodological triangulation (Silverman 1993, Stake 1995). In general, however, methodological triangulation is difficult to pursue in a study targeted at analysing conditions for policy integration as such empirical data are not found in written form but instead drawn from the stories and statements of interviewees.

\section{Environmental policy integration over time}

In the following section we present the analysis on how the capacity to integrate environmental sustainability has evolved over time in Swedish regional development programming and what facilitates or restrict change in different stages of implementation. The analytical questions previously presented in section two are transformed into four analytical categories structuring the empirical analysis. The first concerns the role and status of environmental sustainability, the second deals with the relationship and coordination between key regional development actors, the third targets how a role is secured for environmental sustainability by means of organisation, responsibility and procedures, and the fourth 
illustrates mechanisms for securing a role for environmental sustainability and consequences of the current projectification in programming.

\subsection{The status of environmental sustainability: from compulsory Christmas decoration to increased willingness}

The role and status of sustainable development, and particularly environmental sustainability, has changed over the time period. In 2005 interviewees from all four regions reported on rather fumbling approaches to integrate environmental aspects in the field of regional development. Even though seven years had passed since sustainable development was introduced as a policy task at the regional development arena, it was still perceived as vague and difficult to grasp, a compulsory mantra that was somewhat reluctantly added on the programming documents like Christmas decorations to satisfy national requirements. The idea of regional sustainable development was often questioned and the regional anchorage and ownership was largely missing (Asplund et al 2010, Storbjörk 2008). In the words of one of the interviewees:

"We don't get any political mandate to work with environmental sustainability.

Our task is regional growth" (Focus-group West)

Overcoming this watershed where environmental sustainability was seen as restricting economic sustainability and having low legitimacy among regional development actors was described as mentally challenging. One interviewee expressed the feeling that the regional development arena has "hell of a task ahead" (Focus-group North). Amongst a few particularly motivated and committed actors, with specific tasks to facilitate regional sustainable development or environmental sustainability, there was at the time an explicit willingness for EPI. Generally however, the lack of clarity in objectives and lack of comprehension, willingness, regional support and ownership of national policies served as barriers to implementation (See e.g. Lundqvist 1987).

In 2011 interviewees from several regions reported on both increased awareness and willingness from the regions themselves, supposedly due to changes in overall policy context where public debates about climate change have had a huge impact to legitimise a regional focus on sustainable development (Interviews Mid, West). The interviews suggest that more actors today see synergies between environmental and economic sustainability and report on a number of initiatives strengthening EPI (see section 5.4). At the same time several interviewees also note that it is unclear whether de facto changes can be seen thus raising the problem of willingness vs. action (Interviews South, West). In all three regions with new regional administrative bodies there is still a clear divide between environmental regulation/inspection, which is seen as restricting and problematic for regional growth and development, and environmental sustainability as a strategic approach in terms of innovation, which is seen as potentially supportive for regional growth and development. In these regions some aspects of environmental sustainability - where direct synergies between environmental sustainability and regional growth are more easily spotted e.g. energy-savings and biogas 
efforts - fits within regional programming, while other aspects seen as problematic to deal with - e.g. windmills due to severe land-use conflicts and new road infrastructure due to goalconflicts. We thus find it reasonable to speak of selective or partial EPI where some aspects of environmental sustainability are included and other left out. For the latter there is still a lack of comprehension, capability and support.

\subsection{Actor coordination: from turf battles and disrupted learning to new interactional advances}

A key issue on the regional development arena, that appeared to have a negative imprint on policy integration in the early years of EPI, was the relationship between the traditional CAB and the new regional administrative bodies. The CAB has by tradition had a strong profile in working with environmental sustainability while the new regional bodies have had economic growth as their main task. In 2005 we found evidence of complicated interactions, turf battles and distrust between the $\mathrm{CAB}$ and the new regional bodies in the three regions with new organisational structures for regional development (Asplund et al 2010). In South both parties expressed difficulties in interacting: the regional state actors spoke of the difficulty to engage the $\mathrm{CAB}$ and get the input needed (Focus-group South), while the $\mathrm{CAB}$ spoke of their experience and competence e.g. with environmental sustainability was being circumvented and not included in regional development programming (Interview CAB). In Mid the interviews with the $\mathrm{CAB}$ showed disrupted learning regarding environmental sustainability where the interpretation was that the new regional bodies wanted to make their own imprint on regional development and "run their own race" (Focus-group Mid). Similarly in West the new regional body chose to engage external competence and consultants for matters of environmental sustainability rather than interacting with the CAB (Focus-group West). This suggests, with reference to Vedung, that the intervention comes at a time where one actor is struggling with formation and the other with maintaining positions (Vedung 2005) in a way that creates problems of coordination (Barrett 2004).

Interviews in 2011 suggest that in most regions the interaction has settled somewhat and the new regional bodies and the $\mathrm{CAB}$ are advancing on each other. Taken together, we find three different positions on how the interaction has evolved where the two last positions clearly illustrate that the current division of roles restricts actual implementation and raises questions of who is in charge of what. First, there is the position of a good-spirited attitude where current regional development practices are seen as coordinating complementary positions and competences. In Mid both interviewees express that "we are not strong on our own" describing regional development as a mutual process where the $\mathrm{CAB}$ and the new regional body have complementary competencies. The coordination of competences is seen as the sensible way of using and pooling resources (Interviews Mid). Second, there is the position of a respectful division of work but with little natural platforms for interaction. Interviewees in West (partly South) express that some areas of responsibility are seen as belonging to the new regional body and others to the $\mathrm{CAB}$. There is at times an implicit critique in the interviews of how the other part is handling regional development issues but overall the division of work seems to be accepted. For instance there is no stated need or ambition from the new regional 
body to recruit environmental competencies currently found at the CAB (Interviews West). The third position is that of explicit takeover-ambitions. In South for example the new regional body explicitly have the ambition to take over the responsibility for strategic environmental issues as part of their work on regional development so that the CAB turns into a pure command and control organisation working with environmental regulation and inspection. According to interviews with the $\mathrm{CAB}$ the new regional body have been recruiting competencies from the $\mathrm{CAB}$ in the last years to strengthen their strategic environmental profile and competence. To sum up, even if new interactional advances are identified there still seems to be challenges involved in the communication and coordination of the key implementing actors (Barrett 2004).

\subsection{Securing a role for environmental sustainability: from ambassadors to mainstreaming}

One important aspect in the policy integration process is how a role was secured for environmental sustainability in terms of organisational approaches (Persson 2007). The regions were not given any advice on how to best organise EPI, and we find that rather different approaches were chosen, each creating their particular challenges. In 2005 region West had chosen an approach to concentrate responsibility for sustainable development where one person was given the task to guard and work for sustainable development, describing himself as a rubber band in between actors and sectoral perspectives e.g. the regional management team and external experts on social and environmental sustainability (Focusgroup West). In practice all parties had great expectations of him acting as ambassador of their respective perspectives (Asplund et al 2010: 49). In retrospect this has been described as a vulnerable approach and impossible task for one individual to mantle which also caused tensions in the organisation and made organisational mainstreaming difficult (Interviews West). Region North had a similar ambassadorial approach with a sustainable development team encouraged to lead the way in policy integration. As sustainable development was seen as "mentally very hard" the idea was that a team of specialists working with sustainable development holistically and intellectually could merge different perspectives (Asplund et al 2010: 49). The team however had difficulties to find a role at the regional development arena:

"We seldom hear that it is good that we have required this knowledge but instead it is more like now we have eased our conscience with forming a group. /.../ We have to knock on a lot of doors to show that we want to take part and have competence" (Focus-group North)

The mandate for the team changed somewhat during its operation - from a proactive to a more reactive role - acting less as missionaries and more as informants when other officers got stuck (Focus-group North). The other two regions chose different paths. In South the outspoken policy was that sustainable development ought to be the responsibility of all, suggesting at first glance a more mainstreamed approach but instead specified by there being no need for particular efforts, appointed ambassadors or forums to discuss horizontal goals which would be seen as negative leverage for regional growth and development. In Mid it was 
clear that existing environmental competence was not requested and regional development programming was losing out on sustainable development, compared with precious assessments where the region stood out as a front-line in terms of environmental sustainability (Asplund et al 2010). From the analysis it seems fair to say that the two regions that at the time had made most policy integration efforts in the early years had done so by means of particular ambassadors, with the hope of concentrating attention but with a backside in a lack of organisational mainstreaming, whereas the other could be described as either policy evaporation or disrupted organisational learning (Mickwitz and Kivimaa 2007, Williams 2006).

In the follow-up study from 2011 we identify a more general transition towards an approach of mainstreaming sustainable development in the four regions. The assumption expressed in most of the interviews is that for policy integration to work everyone has to work with sustainable development, hence no particular actor or group of actors can have "monopoly" or specific responsibility for securing this (Interviews West, North, Mid and South). Having one person in charge, as previously in West, is today seen as problematic as it puts the person in an impossible situation of merging perspectives and views which creates a lack of overall ownership (Interviews West). In North, the sustainable development team was gradually fizzled out and seen as functional particularly in an initial phase of EPI:

"The team existed in a starting phase where there was a need for us to learn about sustainable development. /.../ Clearly a lot happened in our process, perspectives changed and we reached a higher level of knowledge on how to deal with the sustainability and the point in taking a wider approach which we carry with us and is more important than any check-list" (Interview North)

Today however, only one of the former team members still works at the CAB and it is up to individual officials to handle sustainable development in their every-day practices and look upon their current business from a sustainable development perspective. Interviews also indicate that although there are channels of dialogue between actors involved in policy integration, questions of representation of the three dimensions still needs to be raised and are often problematic (Interviews North).

The current mainstreaming approach, found in all regions, means that actors in different functions work with various dimensions of sustainable development in parallel. However, responsibility is not necessarily made explicit or viewed in any holistic or systematic way. There is a rich and dynamic flora of organisations at the regional development arena, particularly in the form of networks, clusters and constellations of actors targeted around certain issues e.g. environment and energy, green business etc. In its mainstreamed character, sustainable development today has become more sectorised where different parties and actors work with sustainable development from their various perspectives and priorities (Interviews South, Mid, West and North), supporting the conclusion that the multiplicity of actors poses implementation problems (Barrett 2004) while the interconnectedness of sustainable development dimensions gets lost. Further, many of the current organisations approaching 
regional sustainable development are tied to particular projects or regional development initiatives changing over the years, thus strongly indicating that the status, priority and competence of environmental sustainability varies heavily over time (Interviews South, Mid, West and North). This supports the conclusion of temporary rather than enduring changes (Leroy and Arts 2006, Nilsson 2005). Even though goals are clearly in place there is a risk that goals get lost in the daily work (Interviews West and North). Interviewees state the need for a more strategic representation and competence in regional development forums to secure attention to environmental sustainability (Interviews West). There seems to be a risk of having too many actors with the risk of either double-work or matters falling through the cracks, the latter in line with the discussion on policy dilution, diffusion and/or evaporation where issues might get lost in every-day organisational activities where no ambassadors safeguard perspectives (Liberatore 1997, Williams 2006, Mickwitz and Kivimaa 2007). At the same time the advantages of a mainstreamed approach is that it is seen to create necessary flexibility, common ownership and engagement.

\subsection{Mechanisms for securing a role: from singular pockets of good practice to increased projectification}

The final issue raised in this paper regards what has been accomplished through the policy integration initiatives in the regional development programming context. In the early years, many regional actors regarded the national demands on policy integration as top-down requirements badly suited for regional contexts. They had problems to find appropriate regional mechanisms and applications to supporting implementation beyond overall, rhetorical commitments:

"Sustainable development is integrated if you read programs and plans where it is said right at the beginning that considerations are taken but if you start looking at what the plans contain or lead to then I doubt the integration" (Interview South)

At the time, sustainable development was still described as a new issue to be considered on the regional development agenda. At best examples of singular projects of good practice where e.g. environmental sustainability and regional growth considerations could be met were presented (Asplund et al 2010, Storbjörk 2008).

In 2011, several normative and procedural mechanisms are clearly in place to support a more continuous EPI (Persson 2007). In several regions we find evidence of more concrete commitment and support for the ambitions and goals of environmental sustainability that are expressed in key policy documents (Interviews West, Mid, North). We also find a number of procedural approaches where environmental sustainability is made part of daily routines by e.g. checklists and on the job training to support implementation (Interviews North). Interviewees further report on a number of project activities and initiatives to support EPI. Several interviewees suggest that the project-level is where the real integration takes place (Interviews Mid, West, North). Although regions have chosen to particularly prioritize projects supporting social and environmental sustainability in their declarations related to the 
EU Structural Funds, it is at the same time clear that they don't wait about for the good projects. First come first served, as annual budget have to be used (Interviews Mid, West).

In all regions concrete project activities range from general networks and cluster organisations to support e.g. green business and sustainable energy to concrete project activities and investments in the fields of biogas, energy-efficiency, green business regions, sustainable cities and sustainable mobility (Interviews Mid, North, West, South). Region North gives an interesting addition to the list of possible synergies in mentioning the decontamination of industrial sites and green investments in the process industry as initiatives that attract further investments and opportunities for EPI. These are clearly the issues where environmental sustainability and regional growth and development can be coordinated and synergies have been identified. It is however beyond the empirical scope of this study to say anything more precise about to what extent these initiatives go beyond a more limited coordination of policy objectives to either harmonization or even prioritization in the sense identified by Lafferty and Hovden (Lafferty and Hovden 2003, Runhaar et al 2009, Jordan and Lenschow 2010). Interviewees also speak of other areas where attempts have been made to link together environmental sustainability and regional growth and development, but where the initiatives have been to problematic due to severe land-use conflicts around windmill initiatives or goalconflicts arising in relation to new road infrastructure.

When analysing interview statements about the work undertaken within regional sustainable development initiatives it seems reasonable to speak in terms of a projectification taking place. In general these regional projects come about where there are interested parties - public organisations and/or private actors - who see potential and are prepared to work together. Working in the format of projects is seen as necessary initially, according to our interviewees. The idea is that it is important to invest in promising development projects, knowing that they perhaps don't lead where they are intended. Projects that succeed will find continuation, others will be terminated. Further, the project format is seen as particularly important for those actors that do not have sustainable development as their main task (Interviews Mid, West, South, North).

A number of problems with the projectification are however also identified. Actors working with regional growth and business emphasise the difficulty to get enough turnover to make ecological solutions economically sustainable and able to survive and stand on their own on an open market after the financial state support stops. The need to go beyond "talk-projects" to "growth-promoting projects" that gives real incentives for business is seen as critical (Interviews Mid, West, South, North). Several interviewees also emphasise the difference between rolling out money in projects and get an actual spin on learning in terms of regional sustainable development:

"Learning is our Achilles heel. The focus has been on getting a spin, initiate and mobilise but not in facilitating long-term learning. How to do this in a good way with the many actors in place, the rather big flow of money and the link between projects is tricky" (Interview Mid. See also South) 
In practice the view is rather that there is a lot of focus on initiation and mobilisation but less on accomplishing more durable changes. Due to the nature of short-term projects the projectification creates an unfortunate lack of continuity:

"When projects run out this can lead to us losing out on competence and that matters are no longer put in focus. You have to be able to show concrete results for projects to be able to live on" (Interview West. See also South).

Put in light of previous studies on EPI what we see here is more of temporary rather than enduring changes (Leroy and Arts 2006, Nilsson 2005). A complicating factor here is the often mentioned lack of evaluation and assessments in terms of concrete and measurable effects (Interview Mid, North, South). In connection to learning, the problem of sectorisation and not being able to see the bigger picture is also discussed as different actors work within their particular fields and boxes:

"The cross-sectoral work is acknowledged as important but we all work sectorwise. Projects are designed to accomplish a goal that is not oriented towards learning in the sense of exchanging knowledge, increasing our understanding and acquiring new competence" (Interview South. See also West)

In the interviews the lack of interconnectedness between the different dimensions of sustainable development and how perspectives can be combined restricts learning (Interview West, Mid and South). Again it seems reasonable to speak of selective or partial EPI, rather than the Lafferty and Hovden (2003) way of environmental sustainability having principled priority, and also one that is losing out on both continuity and interaction between sector competencies. It is suggested that too limited arenas for policy integration are created in practice to support the implementation process, even though there are clear goals in place as well as a number of procedural and organisational mechanisms.

\section{Conditions for facilitating long-term policy integration}

With the aim of exploring how the capacity to integrate environmental sustainability has evolved over time in Swedish regional development programming and what facilitates or restricts change in different stages of implementation we can conclude that the capacity of EPI has increased over time. The story from 2005 was centered on weaknesses, flaws and difficulties with somewhat reluctant implementing actors whereas interviews from 2011 illustrate a more enabling regional development context with increased awareness and willingness among implementing actors. Although our study gives evidence of a gradually increasing capacity for EPI over time, it is however still premature to speak in terms of either enduring or substantial changes. Rather it is fair to conclude signs of temporary and partial EPI (Leroy and Arts 2006, Nilsson 2005). It is important to note that the capacity for EPI and what works as barriers or conditions for change varies heavily over time, strongly supporting the view of implementation as an ongoing and dynamic process rather than an end-state. 
Table 2: Summarizing differences in EPI between the early ears (1998-2005) and later years (2006-2011).

\begin{tabular}{|c|c|c|}
\hline & Early years (1998-2005) & Later years (2006-2011) \\
\hline Role and status & $\begin{array}{l}\text { Lack of clarity in objectives, lack of } \\
\text { comprehension, willingness, regional } \\
\text { support and ownership. Sustainable } \\
\text { development as compulsory national } \\
\text { mantra }\end{array}$ & $\begin{array}{l}\text { Increased awareness, willingness and } \\
\text { regional ownership. Selective/partial } \\
\text { EPI emphasizing strategic/innovative } \\
\text { environmental issues }\end{array}$ \\
\hline Actor & $\begin{array}{l}\text { Complicated interactions, turf battles } \\
\text { and distrust. Disrupted learning/ } \\
\text { avoidance and weak coordination }\end{array}$ & $\begin{array}{l}\text { New interactional advances: } \\
\text { complementary positions, respectful } \\
\text { division of work or explicit take-over } \\
\text { ambitions. Challenges of coordination } \\
\text { unsolved }\end{array}$ \\
\hline $\begin{array}{l}\text { Organisation and } \\
\text { responsibility }\end{array}$ & $\begin{array}{l}\text { Initial ambassadors for sustainable } \\
\text { development to concentrate attention } \\
\text { and lead the way. Lack of common } \\
\text { ownership and organizational } \\
\text { mainstreaming }\end{array}$ & $\begin{array}{l}\text { Organizational mainstreaming as } \\
\text { general approach. Flexibility and } \\
\text { ownership but also double-work, } \\
\text { policy-diffusion and sectorisation. } \\
\text { Holistic overview and inter-sectoral } \\
\text { exchange missing }\end{array}$ \\
\hline $\mathrm{Mec}$ & $\begin{array}{l}\text { Difficulty in seeing appropriate } \\
\text { implementation mechanisms and } \\
\text { applications beyond declarations. } \\
\text { Singular pockets of good practice }\end{array}$ & $\begin{array}{l}\text { Regional mechanisms (normative, } \\
\text { organizational and procedural) in } \\
\text { place to support implementation. } \\
\text { Increased projectification but losing } \\
\text { out on continuity, interaction and } \\
\text { learning }\end{array}$ \\
\hline Typ & $\begin{array}{l}\text { First order (incremental routines) and } \\
\text { second order (policy concerns/goals) } \\
\text { change. Temporary and partial } \\
\text { changes }\end{array}$ & $\begin{array}{l}\text { Some signs also of third order change } \\
\text { (core values and perceptions) but not } \\
\text { widespread. Temporary and partial } \\
\text { changes }\end{array}$ \\
\hline $\begin{array}{l}\text { Determinants for } \\
\text { implementation }\end{array}$ & $\begin{array}{l}\text { Lack of comprehension, } \\
\text { administrative capability and } \\
\text { willingness, timing of the } \\
\text { intervention, multiplicity of actors }\end{array}$ & $\begin{array}{l}\text { Multiplicity of actors (challenges of } \\
\text { coordination, } \\
\text { organization/responsibility) }\end{array}$ \\
\hline $\begin{array}{l}\text { Key challenges } \\
\text { ahead }\end{array}$ & $\begin{array}{l}\text { Support/focus/priority beyond policy } \\
\text { rhetoric, applications for regional } \\
\text { sustainable development and } \\
\text { organizational mainstreaming }\end{array}$ & $\begin{array}{l}\text { Go beyond policy-diffusion, } \\
\text { projectification and sectorisation, } \\
\text { create arenas for exchange/interaction } \\
\text { and conditions for continuity, learning } \\
\text { and substantial/enduring change }\end{array}$ \\
\hline
\end{tabular}

More specifically, our findings show a clear difference between first, second and third order change (in line with the Wiering and Crabbé distinction referred to in section 2 above). We see traces of first order change (incremental changes within routine decision-making) and second order change (development of new policy concerns and goals) already in the early years of the process. Results from the interviews in 2011 give some indications of third order change (paradigmatic shift in core values and perceptions), at least when interviewees discuss 
the current status of environmental sustainability and the more easily accommodated strategic aspects of regional sustainable development.

Although there are signs of increased EPI in terms of both normative, procedural and organisational goals and mechanisms, from this does not follow that such changes are represented in regional practices at large. Indeed, there is a problem related to the lack of clearly stated strategies for how to spur a more concrete and fully implemented EPI process out of these mechanisms. The gap between intentions and practice in EPI, as noted in previous studies (Arts and Leroy 2006, Krueger and Gibbs 2007, Nilsson and Eckerberg 2007, Mickwitz and Kivimaa 2007) is valid also for this empirical context and equally in 2005 and 2011. Accordingly, several of our interviewees express a remaining doubt whether real changes are occurring and if these noted changes in values and perceptions are reflected in "fundamental changes in behaviour" (Argyris and Schön 1996) and actual decision-making practices. Here our study suggests temporary and partial rather than enduring and substantial EPI, as suggested above.

In summarizing conditions for change in this temporary and partial EPI we can pinpoint some key differences between interview results in 2005 and 2011. In 2005 the problem was to attract regional support, focus and priority for sustainable development and EPI beyond the national policy rhetoric and to identify relevant regional mechanisms and applications for regional sustainable development. At this stage there were also critical discussions on the aim and content of the sustainable development endeavor and what the practice of EPI could look like, suggesting that the task was both vague and impossible. This suggests that the third implementation determinant related to "comprehension, administrative capability and willingness of key actors" served as a barrier for EPI. These challenges appear significant in an early phase of policy integration where we also witnessed actors struggling to either form or maintain a position in the regional development arena - due to recent reorganizations which had a negative impact on EPI, thus suggesting that "the timing of the intervention" the fourth implementation determinant - created tensions between actors. Further, the multiplicity of actors - the fifth implementation determinant - created problems. At that time it seemed critical to find ways to facilitate organizational mainstreaming rather than merely concentrating responsibility to specific ambassadors as the latter, however important in an initial phase of policy integration, led to a gradual exclusion of sustainable development perspectives in important decision-making forums.

In 2011 the lack of comprehension, administrative capability and willingness for EPI amongst key actors seems to be less of a problem whereas the multiplicity of actors continues to pose problems for implementation. It is clear that organizational mainstreaming both has advantages e.g. providing richness in approaches, common ownership and flexibility but also disadvantages like fragmentation and policy diffusion where a too rampant organizational flora dealing with various aspects of EPI and regional sustainable development leads to lack of overview, risk of double-work and matters falling through the cracks. We conclude that the organisational approaches of either concentrating responsibility or mainstreaming responsibility both have their downsides in terms of implementation. Clearly, the 
organisational mechanisms of how to best pursue EPI is not easily settled. If mainstreaming is preferred, there needs to be mechanisms to make sure that it does not lead to policy evaporation. Further, actor coordination is continuously problematic. Despite the new interactional advances found, there are still unsettled relations in responsibilities which limit current policy integration. Environmental competencies are sometimes involved but the divide between regulative and strategic environmental sustainability creates challenges. Some environmental aspects are included, others not again supporting the conclusion of partial EPI.

The current projectification may be a necessary mechanism for practically initiating activities within the regional development policy field but is characterised by a "first come first served" principle and no follow-up or evaluation of what is actually achieved in terms of sustainable development. Interviewees express strong doubts whether learning occurs in any depth as there is seemingly more focus on initiation and mobilisation rather than achieving long-term learning, capacity-building and securing of critical competences. There is an obvious risk of disruptive activities and lack of continuity. We also find that the sectorisation that follows the current organizational mainstreaming means that different actors remain with their own interpretations of sustainable regional development. There are still no forums and processes that provide arenas for inter-sectoral exchange and mutual learning, which any attempt for systematic policy integration and change in essence is dependent upon.

In general our findings corresponds well with earlier and parallel studies on integrating environmental sustainability in regional growth and development, suggesting that environmental concerns is "partially incorporated but progressively watered down" in implementation (Gibbs 2000: 10, Gibbs et al 2002, Flynn et al 2003, Berger 2003, Valve and Grönqvist 2003). Also in the regional environmental management, similar difficulties in implementation due to value conflicts and power imbalances, boundary maintenance and turf defense and also combined with a generally low political support have been identified (Morrison 2007, Lurie 2011, Robinson et al 2011). To what extent the implementation challenges identified in 2011 will be managed in the next stage of implementation is still to be seen. The main lessons from this longitudinal study are that EPI needs to be analyzed as a gradual process where conditions and determinants for change varies over time. Based on our results we find reasons to problematize the mainstreaming approach in environmental planning and management. Both concentrating and mainstreaming responsibility is needed to tackle challenges in organizational approaches to EPI (Liberatore 1997, Williams 2006, Mickwitz and Kivimaa 2007). Further, our studies suggest that concrete arenas, processes and mechanisms to facilitate cross-sectoral interaction, exchange and learning practices need to be developed accounting for the interconnectedness of the different sustainable development dimensions. Knowledge about the concrete outcomes so far of EPI should be used as an input to these processes as it allows joint reflection on achievements so far and possible ways forward in the process of policy integration.

Finally, we would like to encourage further studies that problematize both the role of policy mainstreaming for effectively pursuing EPI in everyday decision-making practices and how changes in EPI over time can be supported and maintained. With the latter, a particular 
emphasis on measures and interventions with potential to manoeuvre the current problems of policy diffusion and sectorisation in a way that promotes a more enduring reorientation with substantial rather than partial changes in established institutional contexts is particularly warranted.

\section{Acknowledgements}

The empirical results from 2005 stems from the RUSK-project, initiated and designed in cooperation between Eva Asplund, Maria Håkansson and Ann Skantze (KTH, Stockholm), Karolina Isaksson (VTI, Linköping), Tuija Hilding-Rydevik and Sylvia Dovlén, (SLU, Uppsala) and Sofie Storbjörk (Linköping University). To Associate Professor Tuija HildingRydevik for intellectual support, personal engagement and practical opportunities to conduct the needed follow-up study and analysis. To the Swedish Foundation for Strategic Environmental Research (MISTRA) for funding in 2005 and the Swedish Research Council for Environment, Agricultural Sciences and Spatial Planning (FORMAS) for funding in 2011. To the interviewees for openly and generously sharing their perspectives and experiences of environmental policy integration in Swedish regional growth and development programming.

\section{References}

Argyris, C. and Schön, D., 1996. Organizational Learning II: Theory, Learning and Practice. Massachusetts: Addison-Wesley.

Arts, B. and Leroy. P., 2006. Institutional Processes in Environmental Governance: Lots of Dynamics, not Much Change. In: B. Arts and P. Leroy, eds. Institutional Dynamics in Environmental Governance. Dordrecht: Springer.

Asplund E. and Skantze, A., 2005. Hållbar utveckling i praktiken. Möten, gränser, perspektiv. Stockholm: KTH. TRITA-INFRA 05-011.

Asplund, E., et al., 2010. Vårt uppdrag är utveckling - hållbar utveckling och regional tillväxt. Uppsala: SLU. Institutionen för stad och land 2/2010.

Barrett, S.M., 2004. Implementation studies: Time for a revival? Personal reflections on 20 years of implementation studies. Public Administration, 82, 249-262.

Bacchi, C.L., 2009. Analysing policy: what's the problem represented to be? French Forest, N.S.W.: Pearson.

Berger, G., 2003. Reflections on Governance: Power Relations and Policy Making in Regional Sustainable Development. Journal of Environmental Policy \& Planning, 5, 219-234. Dovlén, S. and Hilding-Rydevik, T., 2008. Sustainable Development in Regional Development Practice - a socio-cultural view on evaluation. In: Khakee. A., ed. New Principles in Planning Evaluation. Aldershot: Ashgate.

Flynn, A., Netherwood, A. and Bishop, K., 2003. Multilevel Governance and Sustainable Development in Wales. In: W.M. Lafferty and M. Narodoslawsky, eds. Regional Sustainable Development in Europe. The Challenge of Multi-Level Co-operative Governance. Oslo: Prosus. 
Frame, B. and Taylor, R., 2005. Partnerships for Sustainability. Local Environment, 10, 275298.

Gerger Swartling, A., et al., 2007. Theory and Methodology for EPI Analysis. In: Nilsson M. and K. Eckerberg, eds. Environmental Policy Integration in Practice. Shaping Institutions for Learning. London: Earthscan.

Gibbs, D., 2000. Ecological Modernisation, regional economic development and regional development agencies. Geoforum 31, 9-19.

Gibbs, D., Jonas, A., and While, A., 2002. Changing Governance Structures and the Environment: Economy-Environment Relations at the Local and Regional Scales. Journal of Environmental Policy \& Planning, 4, 123-138.

Haveri, A., 2008. The Rhetorical Wall and the Politics of Images. Evaluation, 14, 141-155.

Hilding-Rydevik, T., et al., 2011. The Swedish Discourse on Sustainable Regional Development: Consolidating the Post-political Condition. International Planning Studies, 16, 169-187.

Håkansson, M., Hilding-Rydevik, T. and Isaksson, K., 2007. Can Regional Planning Foster Sustainable Development? The Swedish governmental discourse on sustainable regional development versus regional planning practice. Paper presented at the Association for European Schools of Planning Conference, July 2007, Italy.

Jenkins-Smith, H. C. and Sabatier, P. A., 1994. Evaluating the Advocacy Coalition Framework. Journal of Public Policy, Vol. 14, No. 2 (Apr. - Jun., 1994), pp. 175-203.

Jordan, A. and Lenschow, A., 2010. Environmental Policy Integration: a State of the Art Review. Environmental Policy and Governance, 20, 147-158.

Kautto, P. and Similä, J., 2005. Recently Introduced Policy Instruments and Intervention Theories. Evaluation, 11, 55-68.

Krueger, R., and Gibbs, D., 2007. The Sustainable Development Paradox. Urban Political Economy in the United States and Europe. New York: The Guilford Press.

Lafferty, W.M. and Narodoslawsky, M., 2003. Regional Sustainable Development in Europe. The Challenge of Multi-Level Co-operative Governance. Oslo: Prosus.

Lafferty, W.M. and Hovden, E., 2003. Environmental Policy Integration: Towards an Analytical Framework. Environmental Politics, 12, 1-22.

Lehmann, M., 2006. Government-Business Relationships Through Partnerships for Sustainable Development: the Green Network in Denmark. Journal of Environmental Policy and Planning, 8, 235-257.

Lenschov, A., 2002. Environmental Policy Integration. Greening Sectoral Policies in Europe. London: Earthscan.

Leroy, P. and Arts, B., 2006. Institutional Dynamics in Environmental Governance. In: B. Arts and P. Leroy, eds. Institutional Dynamics in Environmental Governance. Dordrecht: Springer.

Liberatore, A., 1997. The integration of sustainable development objectives into EU policymaking: Barriers and prospects. In: S. Baker et al, eds. The politics of sustainable development: Theory, policy and practice within the European Union. London: Routledge. 
Liefferink, D., 2006. The Dynamics of Policy Arrangements. In: B. Arts and P. Leroy, eds. Institutional Dynamics in Environmental Governance. Dordrecht: Springer.

Lipsky, M., 1980. Street Level Bureaucracy. New York: Russell Sage.

Lundqvist, L.J., 1987. Implementation Steering: An Actor-Structure Approach. Lund: Studentlitteratur.

Lurie, S.D., 2011. The CALFED Bay-Delta Program: Lessons from the Rise and Fall of a Large-Scale Ecosystem Management Network. Journal of Natural Resources Policy Research, 3, 251-262.

MIEC (Ministry for Industry, Employment and Communications), 2007. En nationell strategi för regional konkurrenskraft, entreprenörskap och sysselsättning 2007-2013 (A national strategy for regional competetiveness, entrepreneurship and employment 2007-2013). Stockholm.

Mobjörk, M., 2007. Företagsorganisationers roll i regionalt utvecklingsarbete. Stockholm: KTH.

Molitor, R., 2003. The Role of Business and Industry in Promoting and Realizing Regional Sustainable Development. In: W.M. Lafferty and M. Narodoslawsky, eds. Regional Sustainable Development in Europe. The Challenge of Multi-Level Co-operative Governance. Oslo: Prosus.

Mickwitz, P. and Kivimaa, P., 2007. Evaluating Policy Integration: The Case of Policies for Environmentally Friendlier Technological Innovations. Evaluation, 13, 68-86.

Morrison, T.H., 2007. Multiscalar Governance and Regional Environmental Management in Australia. Space and Polity, 11, 227-241.

Nilsson, M. and Persson, A., 2003. Framework for Analysing Environmental Policy Integration. Journal of Environmental Policy and Planning, 5, 333-359.

Nilsson, M., 2005. Learning, frames and environmental policy integration: The case of Swedish energy policy. Environment and Planning C: Government and Policy, 23, 207-226.

Nilsson M. and Eckerberg, K., 2007. Environmental Policy Integration in Practice. Shaping Institutions for Learning. London: Earthscan.

Owens, S., 2007. Foreword II. In: M. Nilsson and K. Eckerberg, eds. Environmental Policy Integration in Practice. Shaping Institutions for Learning. London: Earthscan.

Persson, Å., 2007. Different Perspectives on EPI. In: M. Nilsson and K. Eckerberg, eds. Environmental Policy Integration in Practice. Shaping Institutions for Learning. London: Earthscan.

Polk, M., 2010. Sustainability in Practice: The Interpretation of Sustainable Development in a Regional Planning Arena for Dialogue and Learning in Western Sweden. Planning Theory and Practice, 11, 481-497.

Pressman, J.L. and Wildavsky, A.B., 1984. Implementation: how great expectations in Washington are dashed in Oakland : or, why it's amazing that federal programs work at all, this being a saga of the Economic Development Administration as told by two sympathetic observers who seek to build morals on a foundation of ruined hopes. 3rd ed. Berkeley: University of California Press. 
Robinson, C.J. et al., 2011. Policy-level Collaboratives for Environmental Management at the Regional Scale: Lessons and Challenges from Australia and the United States. Society and Natural Resources, 24, 849-859.

Runhaar, H., Driessen P.P.J. and Soer, L., 2009. Sustainable urban development and the challenge of policy integration: an assessment of planning tools for integrating spatial and environmental planning in the Netherlands. Environment and Planning B: Planning and Design, 36, 417-431.

Saetren, H., 2005. Facts and Myths about Research on Public Policy Implementation: Out-ofFashion, Allegedly Dead, But Still Very Much Alive and Relevant. The Policy Studies Journal, 33, 559-582.

Sabatier, P., 1986. Top-down and Bottom-up Approaches to Implementation Research: A Critical Analysis and Suggested Synthesis. Journal of Public Policy, Vol. 6, No. 1, pp. 21-48.

Sanderson, I., 2000. Evaluation in Complex Policy Systems. Evaluation, 6, 433-454.

Silverman, D., 1993. Interpreting Qualitative Data. London: Sage Publications.

Stake, R.E., 1995. The Art of Case-Study Research. London: Sage Publications.

Storbjörk, S., 2008. Experiences of sustainable development policy-integration in Swedish regional development programming: incentives, capacities and inertias. In: B. Frostell, et al., eds). Science for Sustainable Development. The Social Challenge with Emphasis on the Conditions for Change. Proceedings from the $2^{\text {nd }}$ VHU Conference on Science for Sustainable Development. Uppsala: Intellecta DocySys, 239-246.

Storbjörk, S., Lähteenmäki-Smith, K., and Hilding-Rydevik, T., 2009. Conflict or consensus: The challenge of integrating environmental sustainability into regional development programming. European Journal of Spatial Development, 34: 1-22.

Swedish Government 1998: Government Bill 1997/98:62 Regional tillväxt för arbete och välfärd. (Regional growth - for work and welfare).

Swedish Government 2007: Förordning 2007:713 om regionalt tillväxtarbete. (Decree 2007:713 on regional growth organisation).

Swedish Government 2010: Strategiskt tillväxtarbete för regional konkurrenskraft, entreprenörskap och sysselsättning. (Strategic growth organisation for regional competitiveness, entrepreneurship and employment).Government missive 2009/10:221.

Valve, H. and Grönqvist, M., 2003. Regional Policy Reform and the Environment: A Case Study on the Institutionalization of an EU Structual Funding Programme in Gävleborg, Sweden. Journal of Environmental Policy \& Planning, 5: 23-38.

Vedung, E., 2005. Public Policy and Program Evaluation. New Brunswick: Transaction Publishers.

Weale, A., 2009. Governance, government and the pursuit of sustainability. In: N.W. Adger and A. Jordan, eds. Governing Sustainability. Cambridge: Cambridge University Press.

Wiering, M. and Crabbé, A., 2006. The Institutional Dynamics of Water Management in the Low Countries. In: B. Arts and P. Leroy, eds. Institutional Dynamics in Environmental Governance. Dordrecht: Springer.

Williams, P., 2006. The Governance of Sustainable Development in Wales. Local Environment, 3, 253-267. 
Zamora, S.U., 2003. Sectoral Policy Integration and Regional Sustainable Development in Spain: The Case of Galicia. In: W.M. Lafferty and M. Narodoslawsky, eds. Regional Sustainable Development in Europe. The Challenge of Multi-Level Co-operative Governance. Oslo: Prosus. 